\title{
NEPOTISM: ON BEING ONE'S BROTHER'S KEEPER
}

The newly amended Utah anti-nepotism statute, which categorically forbids a public official to hire or retain in public employment his brother or other specified relatives, ${ }^{1}$ was recently attacked in Backman v. Bateman. ${ }^{2}$ There, two school teachers, who had been employed for many years prior to the election of their brothers to their respective local school boards, were notified that the statute prohibited renewal of their teaching contracts for the coming year. ${ }^{3}$ They brought an original action for a declaratory judgment ${ }^{4}$ in the Supreme Court of Utah, claiming that this constituted a deprivation of the property rights that they had in their employment without due process of law. ${ }^{5}$ The court agreed that such application of the statute would be unconstitutional, ${ }^{6}$ reasoning that the state, in the exercise of its police power, could validly limit a right to employment only where there inhered an evil of "substantial nature." Chief Justice Wolfe, concurring, contended that the state's police power was not so limited, and that the condition precedent to state employment imposed by the statute was not so unreasonable as to be invalid. But he observed that the instant application of the statute was unconstitutional in that it deprived the petitioners of property rights in local retirement funds without due process of law. ${ }^{8}$

\footnotetext{
${ }^{1}$ UTAH CODE ANN. $\$ 5^{2-3-1}$ (1953 Supp.): "It is unlawful for any person holding any position the compensation for which is paid out of public funds to retain in cmployment or to employ, appoint, or vote for the appointment of, his or her father, mother, husband, wife, son, daughter, sister, brother, uncle, aunt, nephew, niece, first cousin, mother-in-law, father-in-law, brother-in-law, sister-in-law, son-in-law, or daughter-in-law in or to any position or employment, when the salary, wages, pay or compensation of such appointee is to be paid out of any public funds; and it is unlawful for such appointee to accept or retain such employment in all cases where the direct power of employment or appointment to such position is or can be exercised by any person within the degrees of consanguinity or affinity herein specified, or by a board or group of which such person is a member."

2 I Utah 2d 153, 263 P.2d 561 (1953).

${ }^{3}$ Prior to its amendment, the statute had had no effect where the hiring power was vested in a board and the board member related to the applicant had abstaincel from voting. UTAF CODE ANN. \$ 52-3-1 (1953). See Backman v. Bateman, I UTAH 2d I53, I54, 263 P.2d 56I (I953).

* See UTAH CODE ANN. § 78-33-2 (1953).

I Utah 2d I53, I56, 263 P.2d 56I, 562 (I953).

${ }^{6} I d$. at 557,263 P.2d at 563 . The court also alluded to UTAH Const. ART. XII, \$ I9: "Every person in this State shall be free to obtain employment whenever possible."

I Utah 2d 153, 157, 263 P.2d at 563 (1953).

${ }^{8} I d$. at 160,263 P.2d at 565 . Each of the teachers had contributed to local teachers' retirement funds which contained provisions allowing a teacher leaving the local system
} 
Two justices dissented, being unpersuaded that even these latter rights were such as to merit constitutional protection. ${ }^{9}$

Since the Middle Ages, the favoring of relatives with public or quasi-public positions has been recognized as an undesirable practice. ${ }^{10}$ At least eighteen American states, ${ }^{11}$ in their attempts to control the practice, have enacted constitutional ${ }^{12}$ or statutory provisions directly forbidding it, either in general terms covering all public positions, ${ }^{13}$ with or without specific exemptions, ${ }^{14}$ or by enumerating specific offices. ${ }^{15}$ In

to make double contributions and continue membership, but had no provisions allowing for withdrawal of previous contributions under the circumstances of the principal case. Since the decision in the Backman case, the Utah legislature has abolished all teachers' local retirement funds; contributions are now made to a state fund. Utah Laws Ist Spec. Sess. I953, c. $2 \mathrm{I}$. Subsequent to this enactment, rehearing was denied. in the Backman case.

I Utah 2d 153, 168-7I, 263 P.2d at 570-73 (1953).

${ }^{10}$ See 64 Justice of THE PeAce 257 ( 1900 ).

${ }^{11}$ Arizona, Arkansas, Florida, Idaho, Indiana, Iowa, Kansas, Mississippi, Missouri, Montana, Nebraska, New Mexico, North Dakota, Ohio, Oklahoma, South Carolina, Tennessee, and Utah. In at least four other states, a husband-wife relationship has been held to be a disqualifying interest under a statute which forbids a public officer to have an interest, either direct or indirect, in a public contract. See, e.g., Woodward v. City of Wakefield, 236 Mich. 417, 210 N.W. 322 (1926); Harrison v. City of Elizabeth, 70 N.J.L. 59I, 57 Atl. I32 (I 904); Sturr v. Borough of Elmer, 75 N.J.L. 443, 67 Atl. 1059 (1907); Low v. Town of Madison, I 35 Conn. I, 60 A.2d 774 (1948); cf. Haislip v. White, 124 W.Va. 633, 22 S.E.2d 36I (1942). See generally Note, 74 A.L.R. 792 (1931).

${ }^{12}$ See, e.g., Ark. Const. Amend. XXXV, \& 8; Mo. Const. Art. 7, § 6; Utafi Const. ART. VIII, $\S$ I5.

${ }^{13}$ E.g., NEb. REv. Stat. $\$ 8$ I-108 (1943): "No appointee in any of the departments shall be relatives of any of the heads of departments created by Section 81-10i." See also Idaho CODE $\$$ 59-7OI (1947); MONT. REv. CODE $\$ \S 59-5$ I $8,59-5$ I9, 59-920 (1947); S.C. CODE $\$$ 50-ror (r952).

${ }^{1 *}$ E.g., ARIz. CODE ANN. \$ 54-4I6 (I939) (exempts school teachers if the school board unanimously votes to accept); FLA. STAT. ANN. § I I6.10 (I94I) (exempts those who employ only one person within the prohibited degree of relationship); IowA CODE ANN. $\$ 7$ r.1 ( 949 ) (exempts principal if supervisor who approves his bond also approves his appointment, or if appointee is either a school teacher or earns less than $\$ 600$ a year); MIss. CODE ANN. $\S_{405}$ I (1942) (exempts relative who was in subordinate position when "his or her kinsman" became head); TEX. PEN. CODE arts. 43r, 438 (Vernon 1952) (exempts appointee who has held job two or more years prior to the placement of relative, notaries public, and assistants of legislators who need help as a result of physical infirmities); N.M. STAT. ANN. $\$$ ro-IIo (r94I) (exempts teachers and also employees who make less than $\$ 600$ a year).

${ }^{15}$ E.g., ARk. Stat. ANN. (1947) § $21-649$ (tax collectors in levee districts), \$39201 (jury commissioners), $\$ 47-116$ (fish and game commissioner), $\$$ 72-1216 (massage board of examiners), $\$ \S 80-1$ I8, 80-217, 80-2I9, 80-509, 80-5 I0, 80-511, 80-2509, 80-253 $\mathrm{I}, 80-2819,80-2520,80-3115$ (widely varying phases of public education), \$ 83-120 (public welfare department); KAN, GEN. STAT. ANN. (I949) § I3-2903 (first-class cities), $§ I_{4}-537$ (second-class cities), $\$ 20-901$ (district court reporters), 
most of these cases these provisions, standing alone, do not contemplate the effect of the prohibition. ${ }^{18}$ Yet, some courts have held that where the appointee's qualifications have been objectively established, the antinepotism provisions do not apply, since they are aimed only at the elimination of inefficiency. ${ }^{17}$ Other courts, however, have taken judicial notice of the "evil inherent" in the practice itself and have enforced the prohibition without regard to the appointee's qualifications. ${ }^{18}$

The conflict exhibited by the opinions in the Backman case illustrates this divergence of judicial attitudes as to the effect of anti-nepotism provisions rather than a divergence as to whether or not a state may properly control the practice. Courts have consistently upheld the right of a state to prohibit the appointment of relatives to public office on broad policy grounds, accepting almost without question the standards imposed by the legislature. ${ }^{19}$ And although in giving advisory opinions, several

$\S 28-706$ (county jail matrons), $\S \S 72-1347,72-1348$ (school teachers), $\S 74-2411$ (state commissioner of internal revenue), $\S 74-605$ (state corporation conımissioner), $\S$ 76-101 (state institutions), $\S 76-1504$ (state sanatorium). In Kansas, relationship within the ninth degree has been held sufficient to disqualify. Bailey v. Turner, 108 Kan. 856, I97 Pac. 214 (1921).

${ }^{18}$ See, e.g., N.D. REv. Code $\$ 44-0409$ (1943): "No head of any executive or administrative department, either elective or appointive, of this state, shull appoint his wife or her husband, as the case may be, son, daughter, brother or sister, to any position under the control or direction of said head of such department."

${ }^{17}$ E.g., State ex rel. Robinson v. Keefe, I I I Fla. 701, I49 So. 638 (1933). Cf. State ex rel. Pittman v. Barker, I 13 Fla. 695, 152 So. 682 (1934); MONT. REV. CODE \& 59-5 18 (1947): "Nepotism is the bestowal of political patronage by reason of relationship rather than of merit."

${ }^{18}$ See, e.g., Reddell v. State, I4 Okla. Cr. 199, 170 Pac. 273 (1918); Barton v. Alexander, 27 Idaho 286, 148 Pac. 471 ( 1915$)$. The charge of hiring relatives has even been held libelous per se, though no statute prohibited it. Parmerlee v. Nottage, 119 Minn. 351,138 N.W. 312 (1912); of. Houston Chronicle Pub. Co. v. Wegner, I 82 S.W. 45 (Tex. Civ. App. Ig16). And one commentator has observed that it is no more valid to say that hiring relatives for public office should be condoned if the appointee is qualified than it is to say that the buying of public offecs is not to be condemned if the purchaser is well fit for the position. 64 JUSTICE OF THE PEACE 257 (1900).

Penalties for violation of anti-nepotism statutes range from fine and imprisonment to forfeiture of compensation. E.g., MISs. CoDE ANN. § 2923 ( 1942 ) (penalty of not less than $\$ 25$ nor more than $\$ 500$, up to six months imprisonment or both); MoNT. REv. CODE $\$ 59-920$ ( 1947 ) ( $\$ 50$ to $\$ 1000$, six months imprisonment, or both); N.D REv. CODE $\$ 44-04$ 10 (I943) (salary of appointor assessed to regain money paid out); OHIO REv. CODE $§ 33$ I9.2 I (Page 1954) (contract in violation void); IOWA CoDE ANN. § 7 I.2 (1949) (bondsman and principal liable for moneys paid out). See State ex rel. Robinson v. Keefe, II Fla. 701, 149 So. 638 (1933) for an opinion that such statutes, being penal, must be strictly construed.

${ }^{10}$ E.g., Reddell v. State, 14 Okla. Cr. 199, 202, 170 Pac. 273, 274 (1918). See Barton v. Alexander, 27 Idaho 286, 297, 148 Pac. 471, 475 (1915), where the 
state courts have held that proposed anti-nepotism statutes would violate the Federal Constitution, ${ }^{20}$ it seems unlikely that the United States Supreme Court would so hold if it were confronted with this question. In Atkin v. Kansas, ${ }^{21}$ the Court held that the state could prescribe the conditions upon which it would permit public work to be done. And in Kotch v. Board of River Port Pilot Commissioners, ${ }^{22}$ it upheld a statute which, in effect, required that an applicant be related to a member of the appointing board as a condition precedent to his employment, noting that a state has the right to select its own employees in its own way so long as it is not arbitrary. ${ }^{23}$

The most compelling policy underlying anti-nepotism provisions would appear to be the minimization of governmental inefficiency. ${ }^{24}$ Accordingly, where a separate law requires a specific competence as a prerequisite for appointment to a specific position, this end would seem to have been served, and anti-nepotism provisions would seem, in spirit, to be inapplicable. ${ }^{25}$ Where, however, the court feels that this construction is foreclosed by the liberal language of the anti-nepotism provision itself, ${ }^{26}$ there would seem to be no constitutional bar to its un-

court said, "We believe it to be within the legislative power to prohibit officers from appointing persons related to them by affinity or consanguinity, in the interest of efficiency in public service and for the best interests of the people and of the municipal subdivisions of the state, and as a legitimate police regulation, in regard to which the law-making power may legislate, and reasonable regulation in regard thereto is constitutional and enforceable. Nepotism ... ought to be eradicated . . . and we know of nothing . . that prohibits . . passing reasonable regulations in regard thereto."

${ }^{30}$ E.g., Opinion of the Justices, 303 Mass. 63I, 22 N.E.2d 49 (1939); Opinion to the House of Representatives, 96 A.zd 623 (R.I. 1953). But. cf. Wayne County v. Steele, I2 I Neb. 438,237 N.W. 288 (193I).

21 191 U.S. $207(1903)$.

22330 U.S. $552(1947)$.

${ }^{23}$ Id. at 557. See also Wieman v. Updegraff, 344 U.S. 183 (1952) ; Adler v. Board of Education, 342 U.S. 485 (1952); Gerende v. Board of Superiors, 341 U.S. 56 (1951); Garner v. Board of Public Works, 34I U.S. 716 (I951). Although a retroactively operative statute might be attacked as "arbitrary" or "unreasonable," the Court, significantly, has never invalidated a statute on that ground alone. Cf. cases cited in note 27 infra. The Court has also held that a government employee has no property right in a public position. Dodge v. Board of Education, 302 U.S. 74 (1937); Taylor v. Beckham, 178 U.S. 548 (1 goo); Crenshaw v. United States, 134 U.S. 99 (1890). Cf. McAuliffe v. New Bedford, 55 Mass. 216, 29 N.E. 5 I7 (1892).

"See note $I 7$ and accompanying text supra.

${ }^{25}$ See note 19 and accompanying text supra. This conclusion would also seem to have been codified, in substance, in those states whose statutes provide that the antinepotism provisions shall not apply where the appointee has held his office a certain length of time before his relative-appointor takes his position. E.g., TEX. PEN. CODE art. 432 (Vernon 1952); Miss. CODE ANN. $\$ 4051$ (1942). See also Opinion to the House of Representatives, 96 A.2d 623, 625 (R.I. 1953).

${ }^{20}$ The courts seem to assume that the statutes apply without regard to the applicant's 
restricted application, provided that the standard employed is definite and not arbitrary. ${ }^{27}$ Thus, the court in the Backman case, in construing an anti-nepotism provision of this latter type as it did, appears to have substituted its judgment for that of the legislature and, to this extent, would appear to have exceeded the limits of judicial propriety.

Paul V. Evans

qualifications. See, e.g., Barton v. Alexander, 27 Idaho 286, 148 Pac. 471 (1915), notc I9 supra. But cf. State ex. rel. Robinson v. Keefe, 11 I Fla. 701, 149 So. 638 (1933).

${ }_{27}^{27}$ See notes $2 \mathrm{I}-23$ and accompanying text supra; cf. Cummings v. Missouri, 4 Wall. 277 (U.S. 1867 ); Ex parte Garland, 4 Wall. 333 (U.S. 1867). In both of these cases the Supreme Court invalidated acts which expressly disqualified certain named persons from holding public office as being in the nature of a bill of attainder. The weakness of such acts was said to lie in the fact that they disqualified a person or class of persons for reasons which were not disqualifying factors at the time the jobs were given and which did not test the person's ability. 